\title{
"How Beautiful It Sounds!": The Lieder and Sonntagsmusiken of Fanny Mendelssohn Hensel
}

\author{
Sabrina Baeta \\ School of Music, College of the Arts, University of Florida \\ Faculty mentor: Brenda Smaith, School of Music
}

\begin{abstract}
Throughout her lifetime, Fanny Mendelssohn Hensel (1805-1847) was primarily known as the sister of the famous composer Felix Mendelssohn (1809-1847), as the daughter of her distinguished parents Lea and Abraham Mendelssohn, and as the wife of her artistic husband, August Wilhelm Hensel (Hensel 16 Songs 3-4). Today, however, Hensel is remembered for her remarkable musical talents and a wide breadth of compositions. Though often passed over as a woman of the nineteenth-century, Fanny Hensel played a key role in Berlin's musical culture. Hensel's musical voice was defined by her comprehensive education and through her Sonntagsmusiken (translated "Sunday Musicales"). In the next generation, British author Virginia Woolf shed light on the obstacles present in a female artist's life. In the essay, A Room of One's Own, Woolf outlined the main elements necessary to create art: financial security and a room to one's self. For Hensel, financial security was ensured through her family, yielding a rich musical education for the composer. This paper investigates how Fanny Mendelssohn Hensel's educational and performance opportunities shaped her compositional voice and defined her influence on nineteenth-century Berlin musical society.
\end{abstract}

\section{Introduction}

When Fanny Mendelssohn Hensel was born, her mother said she had Bach'sche Fugenfinger, or fingers suitable for playing Bach fugues (Tillard 35). At thirteen, Hensel memorized all twenty-four preludes of Bach's Well Tempered Clavier in honor of her father's birthday (Wallace 7). One year later, she composed her first lied for the same occasion. Her talents, though, were not honed for the purpose of a professional career. Hensel was called a prodigy, but was told that music would only serve as an "ornament" to her life (Todd 48). When her brother Felix Mendelssohn continued his intellectual and musical studies, Hensel learned "domestic arts and subjects" (Todd 23). It was only in 1846 that Hensel finally joined the composer's "guild" by publishing, but her time on earth was cut short less than a year later (Todd 316).

Virginia Woolf's A Room of One's Own sheds light on the obstacles pervading the female artist's life. Woolf outlines the two elements necessary to create art: financial security and a room to oneself. Fanny Hensel used her family's financial security to her advantage, receiving 
and benefiting from a lively musical education. She went on to form her own creative space in the Sunday concerts she organized in Berlin. Perhaps Hensel did speak her mind, though, and in the only way she knew how-through her music.

Hensel's musical impact can be traced in the countless letters and diaries kept by the Mendelssohn family, and even in the published works of her brother. As an established composer in July 1842, Felix Mendelssohn paid a visit to Queen Victoria and Prince Albert at Buckingham Palace. Shuffling through the Queen's music, Felix spotted his first set of published songs and asked the Queen if she would be willing to sing one. She agreed, choosing "Italien" (Quin 45). After accompanying the Queen, Felix decided to reveal the song's true authorship. He described the experience in a letter to his family, stating "I was obliged to confess that Fanny had written the song (which I found very hard, but pride must have a fall), and to beg her to sing one of my own, too" (Quin 46).

Though she did not publish until the year before her death, Hensel's compositions still found praise across Europe during her lifetime. Felix Mendelssohn's 12 Gesänge, Opus. 8 featured two other compositions by his sister besides "Italien" with the lied "Das Heimweh" and the duet "Suleika und Hatem". Hensel's friends and family knew of her contributions, but the public was not aware. Three years after the set was published, John Thomson, an English musician and friend of Felix Mendelssohn's, visited Hensel in Berlin (Tillard 166). A correspondent to the music journal The Harmonicon, Thomson wrote of the set, "I possess twelve published songs under Mr. Mendelssohn's name... but three of the best are by his sister, a young lady of great talents and accomplishments... Her songs are distinguished by tenderness, warmth, and originality" (Quin 46). Thomson went on to recognize Hensel's talent as a "first-rate piano-forte player", and her ability to compose "with the freedom of a master" (Quin 45).

Hensel's influence stretched beyond the confines of her music room, and were most notably felt in her own city, Berlin. Through her Sonntagsmusiken, Hensel played a key role in the musical life of Berlin, while still developing her own compositional voice regardless of the limitations placed on her gender.

\section{Hensel's Musical Education}

Fanny Hensel's education gave her a deep appreciation for a variety styles, and acquainted her with the best musical minds of Berlin. As Lea and Abraham Mendelssohn's eldest child, Hensel 
was doted on by her parents. The actor Eduard Devrient described Lea as "a woman of great intelligence and culture as well as an alert mistress of the house" (Tillard 55). Hensel's father Abraham "exercised firm authority and received warm love", a trend that would carry throughout Hensel's life to both positive and negative effects on her musical career (Hensel 16 Songs 4).

To the family, education and love were inseparable - to succeed in one was to validate the other. Hensel's early talents were nurtured and encouraged by both parents, and a diligent and rigorous work ethic was instilled within her. Four years after Hensel's birth, Felix Mendelssohn came into the picture. The two siblings became inseparable allies and musical confidants, studying and playing together, and often contributing to each other's early compositions. In a letter from 1822, Hensel wrote, "[I am] his only musical adviser, and he never writes down a thought before submitting it to my judgement" (Mace 5). However, as a woman of high class standing in the nineteenth-century, Hensel was not expected to pursue music professionally or publicly. Even as her knowledge and talents assisted Felix, it was only through him that she could receive certain educational privileges, such as her time studying at the Berliner Singakademie (Citron 570).

In 1818, Carl Friederich Zelter, director of the Berliner Singakademie, was hired to teach composition to both Felix and Hensel. Zelter "trained them in the tradition of Bach, Kirnberger, and Fasch" in "an extremely rigorous method, based on models... accompanied by multiple exercises in counterpoint and figured bass" (Tillard 66). As the voice of the Romantic era was being shaped, Hensel was immersed in the Classical methods. Hensel, however, still found inspiration from her contemporaries. In Fanny Hensel: The Other Mendelssohn, R. Larry Todd writes about the influence that Ludwig van Beethoven's compositions had on Hensel, stating that they "acted as a liberating force" for her, where "she found new, flexible approaches to classical forms and tonal organization" (182). Hensel's lieder reflect a blend of the Classical harmonic structures of Bach combined with a Romantic freedom reminiscent of Beethoven (Todd 31).

\section{Hensel's Compositional Style in the Lieder Genre}

In A Room of One's Own Virginia Woolf writes, "It is strange how a scrap of poetry works in the mind and makes the legs move in time to it along the road" (Woolf A Room 12). Though 
born more than eighty years before Woolf, by this standard, Fanny Mendelssohn Hensel must have done a lot of walking. She composed nearly 250 lieder in her lifetime (Rodgers 176). In the article, "Fanny Hensel's Lied Aesthetic," Stephen Rodgers comments that Hensel's style comes from "a keen sensitivity to poetic nuance, a penchant for experimentation, and a strong interpretive streak" (179). She took more compositional chances than Felix, "generally more dramatic, more text-driven, and more harmonically audacious" (Rodgers 177). In a letter from 1835, Hensel described to Felix her relationship with the lieder genre, as compared to larger song genres:

"It is not so much the compositional skill that is lacking as a certain approach to life, and because of this deficiency my longer pieces are already dying of old age in their infancy... That's why I'm best at writing lieder, where an appealing idea may suffice, without much strength to develop it." (Tillard 225).

Hensel does not lack the "compositional skill" to succeed in larger genres, but rather the domestic freedom to compose unimpeded. Hensel's concentration must have always been broken by what Woolf references as the "casual interruptions" of domestic life, such as child care and female social obligations (Woolf A Room 56). However, Wolf continues to state that these emotional responsibilities helped women become experts on "the observation of character, in the analysis of emotion." (Woolf A Room 56). For Hensel, that was what the lieder genre represented. In one song setting, Hensel could select "an appealing idea" within a poem and amplify the character and emotion it offered. She did not shy away from texts set to music by other notable composers, such as Beethoven and Robert Schumann, and set many of the distinguished poets of her day. This list includes Heinrich Heine, Joseph von Eichendorff and most of all, Johann Wolfgang von Goethe.

Nearly a tenth of Hensel's lieder output was based on texts by Goethe, who was beloved by composers for the natural musicality of his words, and for blurring the line "between pure poetry and poetry for music" (Campbell 58). Moreover, Goethe and Zelter were good friends who maintained an active correspondence with each other. In 1821, Zelter took a young Felix to meet Goethe. One year later, Hensel visited the poet as well, and must have left quite an impression. Goethe wrote to Felix in 1825, "Remember me to your good parents, your equally gifted sister, and your excellent master" (Citron 578). 


\section{The Sonntagsmusiken, or "Sunday Musicales"}

With her own developed style, and without the pressure of composing for the intent to publish, Hensel was fulfilling Woolf's definition of the artist. She had financial security and was composing with a "freedom of mind" to only undertake projects she found fulfilling (Woolf A Room 54). All that was left for Hensel was a room of her own. In 1821, the Mendelssohn family began their Sonntagsmusiken, or "Sunday musicales," a tradition that would come to define not only Hensel's artistic output, but Berlin musical life in the nineteenth-century (Bodley 52). Abraham and Lea Mendelssohn, seeking an audience for their musically gifted children, started the Sunday musicales. In the musicales, musicians gathered at the Mendelssohn household to act as audience members and performers, attracting some of the most notable musical names of the time. Three years after the musicales first began, the family moved to a more spacious house with a Gartenhaus, or "garden house" (Todd 86). This Gartenhaus would become central to Hensel's personal and musical life. Sebastian Hensel, Hensel's only son, wrote about Hensel and Felix's experiences, "the children got accustomed to play before an audience, and had an opportunity of hearing other people's judgment. Even then, all musicians of distinction passing through Berlin requested to be admitted to these musical entertainments" (Wallace 13). It was in the Gartenhaus that Hensel would finally find a room of her own.

The year 1829 saw Felix leaving Berlin for his grand tour as a composer, while a twenty-three year old Hensel stayed behind and married the painter Wilhelm Hensel. They subsequently moved into the Gartenhaus by her parents (Bodley 53). Though entirely unmusical himself, Wilhelm provided indispensable encouragement for Fanny Hensel as a composer. Sheila Hayman, the great-great-great granddaughter of Hensel says of Wilhelm, "every morning of their marriage, before [Wilhelm] went off to paint, he would put a piece of blank manuscript paper on [Fanny's] music stand and tell her he wanted to see it filled up when he returned" (Hayman). Even with this support though, Hensel's compositional output faced mounting obstacles. She was without her trusted musical advisor, Felix, and was confronted with new domestic duties, all while the musicales of her childhood had ceased.

Hensel decided to fill this void by reinstating the family musicales in 1831, an idea highly encouraged by her supportive husband (Quin 59). In a letter to Hensel, Felix also wrote of his own support for the project, "I cannot tell you, my dear Fanny, how pleased I am by your plan for the new Sunday music [series]. That's a brilliant idea and I implore you in God's name not to 
let it slip into oblivion" (Bodley 53). The Neue Sonntagsmusiken, or "New Sunday Musicales", provided Hensel with newfound encouragement and inspiration. On October 7th, 1831, Hensel wrote in her diary "My Sunday concert series are really prospering and bring me great joy" (Bodley 53). The Sunday musicales gave Hensel free reign to act not only as a performer, but as a programmer, conductor, and composer. What started with "small beginnings" as "meetings of a few intimate friends on a Sunday morning," grew to include notable guests such as Nicolò Paganini, Joseph Joachim, Carl Maria von Weber, Charles Gounod, Franz Liszt, Jenny Lind, Heinrich Heine and Clara and Robert Schumann (Quin 240, Wallace 34). The pieces performed ranged from Bach cantatas to choral works by Felix, from scenes from Beethoven's Fidelio to selections from Mozart's operas (Bodley 54). Hensel's own pieces were often debuted in the Gartenhaus, from her choral works to her Trio in D minor (Bodley 264).

In the article "In Pursuit of a Single Flame: Fanny Hensel's 'Musical Salon," Lorraine Byrne Bodley comments on the relief these types of musical gatherings offered to women, stating that they were "where women were able to escape from social, gender and, to some extent, religious prejudice" (48). To truly experience her compositions, Hensel needed them to be performed and listened to by musicians of her caliber and tenacity. Hensel found her audience in the Gartenhaus in Berlin. From 1833 until her death in 1847, Hensel hosted over seventy-five performances (Hensel Tagebücher 49-51). She created opportunities to showcase her work without going against the wishes of her father and brother, who did not want her to become a public, published composer. The impact the musicales played on Hensel may be best summed up by her own words, "I'm quite busy with my music and am enjoying it immensely. I had thought that such pleasure was only a thing of the past and am truly very happy with my life... I haven't enjoyed myself as much as this summer since I was a child" (Wallace 61).

The encouragement she received from her musicales, along with the artistic inspiration spurred on by a trip to Italy in 1839 , helped Hensel begin to seriously consider publishing her works (Quin 260). With her father's passing in 1835, and her mother and husband's support for the project, Hensel only had her brother to appease. When he would not offer his support, she still continued with her plans. So, at the age of 40, Hensel finally saw her Op. 1 published (Hensel 16 Songs 3). Felix only consented after receiving a letter from Hensel. She explained that she had accepted an offer from the publisher Bote and Bock, who had been asking to publish her works for several years (Mace 260). Felix wrote in a reply from 1846, "[I] give you my professional 
blessing upon your decision to enter our guild. I give it to you now, Fenchel, and may you obtain satisfaction and joy from providing delight and joy to others" (Todd 316). Hensel had finally joined that "guild" of published composers and was able to draw claim to a full work, entirely her own.

\section{Conclusion}

Hensel's other works, however, would not be hers to publish. On May 14th, 1847, she sat at the piano, rehearsing with her Sonntagsmusiken choir. They were preparing for a performance of Felix's Die erste Walpurgisnacht, a piece Felix had composed shortly after Hensel informed him of her intent to revive the family musicales. After losing feeling in her hands, Hensel summoned a replacement to take over accompanying duties on the piano. She walked into the adjoining room, calling out to her musicians, "How beautiful it sounds!" (Todd 344). Soon after, she lost consciousness and died in her family home, in the Gartenhaus where the center of her life was spent.

Hensel's death was deeply felt by her family, and by the entire city of Berlin. The musical critic Ludwig Rellstab wrote in an obituary to Hensel:

On Sunday mornings there took place... musical gatherings of the rarest kind, where classical works of older times and the best of the present were heard in the most scrupulous performances, and where the audience's enjoyment was enhanced by the participation or presence of the most distinguished artists who ever lived in our city or visited it... That is a service for the artistic standards of our city for which we are deeply obliged! (Todd 346-7)

To Felix, the loss was shattering. Without his greatest musical confidant and Fenchel, his health declined. Less than six months after Hensel's death, Felix too passed away. He was taken to Berlin and buried alongside his sister (Tillard 19). Fanny Hensel's husband, Wilhelm, remained faithful to his beloved wife. After her death, he pushed to have her compositions published, at first with Felix and then on his own. His painting faltered, and he never returned to that medium, turning to politics instead (Todd 353). Wilhelm could be content knowing he had been Hensel's chief supporter and a constant source of comfort for the composer. The day before her death, Hensel told her husband, "'I'm happier than I deserve to be," to which he replied, "'If you don't deserve to be happy, then who ever does?" (Tillard 332). It was left to Sebastian Hensel, Fanny and Wilhelm Hensel's only child, to continue the Mendelssohn tradition. In 1879, 
he published Die Familie Mendelssohn 1729-1847, detailing the history of his family from his great-grandfather, the Jewish scholar Moses Mendelssohn, up until Hensel and Felix's deaths (Todd 356). In his last recollections of his mother, Sebastian put into words the legacy and character of Fanny Mendelssohn Hensel:

Her movements were quick and decided, and her countenance full of life, faithfully reflecting every change of mood. She never could disguise her feelings, and everybody soon found out what she thought of them... Luxury and creative comforts she was indifferent about, caring nothing for good eating and drinking, good accommodation, dress, or any articles of clothing. What she did require was intercourse with a few refined and clever people, and the pleasures of art. The love of liberty was deeply rooted in her character; she held aloof from people who prided themselves either on their birth or their wealth. She had a great aversion to paying calls and other 'social duties' and kept out of all such as much as possible. She was the most faithful and constant of friends to all she thought worthy of her intimacy, and capable of any sacrifice for their sake (Todd 345).

Hensel did not live long enough to see all of her compositions published, or to truly experience life as a public composer. For a century, she was forgotten as anything more than the sister of the famous Felix Mendelssohn. Her music, however, transcends time. Woolf's words speak to the endurance of art and the artist that creates it, "[The artist] lives in you and in me, and in many other women who are not here tonight... if we have the courage to write exactly what we think... then the opportunity will come" (Woolf A Room 95). Hensel saw her opportunity in a "scrap of poetry" and in "the observation of character, in the analysis of emotion" (Woolf A Room 12, 56). Hensel lived with a remarkable "freedom of mind" that allowed her to compose as she wished (Woolf A Room 54). Through her music, we hear how Hensel had "the courage to write" (Woolf A Room 12). Today, Fanny Mendelssohn Hensel is remembered for her musicality, her cultural influence in Berlin, and for her vast collection of works. It appears Madame Hensel did have more to say than she let on-and say it she did.

\section{Acknowledgements}

Thank you to my research mentor, Dr. Brenda Smith, for providing me with indispensable advice and guidance during this project. Thank you also to Alan Asher at the University of Florida's Architecture and Fine Arts Library, and to the librarians at Harvard University's Loeb Music Library for their time and materials. 


\section{References}

Beer, Anna. Sounds and Sweet Airs: The Forgotten Women of Classical Music. Oneworld Publications, 2016.

Bodley, Lorraine Byrne. “In Pursuit of a Single Flame: Fanny Hensel's 'Musical Salon.” Women and the Nineteenth-Century Lied, edited by Susan Wollenberg and Aisling Kenny, Ashgate Publishing, 2015, pp. 45-59.

Campbell, Stephanie L. "Carl Friedrich Zelter and Text Setting: A Comparison of Goethe Settings by Zelter, Beethoven and Schubert." Dissertation, Washington University, 1997. EBSCOhost, search.ebscohost.com/login.aspx?direct=true \&AuthType=ip,uid\&db=rih\&AN=A212699\&site=e host-live.

Citron, Marcia J. “The Lieder of Fanny Mendelssohn Hensel.” The Musical Quarterly, vol. 69, no. 4, 1983, pp. 570-594. JSTOR, http://www.jstor.org/stable/741981. Accessed 3 Dec. 2017.

Draper, Brian W. "Text-Painting and Musical Style in the Lieder of Fanny Hensel." Dissertation, University of Oregon, 2012, https://scholarsbank.uoregon.edu/xmlui/bitstream/handle/1794/12441/Draper_oregon_0171N_10 433.pdf; sequence=1. Accessed 29 March 2018.

Hayman, Sheila. “A Fanny Mendelssohn Masterpiece Finally Gets Its Due.” The Guardian, 8 March 2017, https://www.theguardian.com/music/2017/mar/08/fanny-mendelssohn-easter-sonatapremiere-sheila-hayman. Accessed 5 Nov. 2017.

Hensel, Fanny. Fanny Hensel Tagebücher. Breitkopf \& Härtel, 2002.

Hensel, Fanny Mendelssohn. Fanny Mendelssohn Hensel 16 Songs. Edited by John Glenn Paton, Alfred Publishing Co., 1994.

Mace, Angela Regina. "Fanny Hensel, Felix Mendelssohn Bartholdy, and the Formation of the Mendelssohnian Style.” Dissertation, Duke University, 2013, https://dukespace.lib.duke.edu/dspace/bitstream/handle/10161/7150/Mace_duke_0066D_11802.p df?sequence=1\&isAllowed=y. Accessed 29 March 2018.

Quin, Carol Lynelle. "Fanny Mendelssohn Hensel: Her Contributions To Nineteenth-Century Musical Life." Dissertation, University of Kentucky, 1981. EBSCOhost, search.ebscohost.com/login.aspx?direct=true \&AuthType=ip,uid\&db=rih\&AN=A416855\&site=e host-live.

Rodgers, Stephen. "Fanny Hensel's Lied Aesthetic.” The Journal of Musicological Research, vol. 30, no. 3, 2011, pp. 175-201. ProQuest, https://search.proquest.com/docview/893998479?accountid=10920. Accessed 3 Dec. 2017.

Tillard, Françoise. Fanny Mendelssohn. Translated by Camilee Naish, Amadeus Press, 1996.

Todd, R. Larry. Fanny Hensel: The Other Mendelssohn. Oxford University Press, 2010. 
Wallace, Sean M. H. “The 'Gartenlieder', Op. 3, of Fanny Mendelssohn Hensel (1805-1847).” Dissertation., Michigan State University, 2000, EBSCOhost, search.ebscohost.com/login.aspx?direct=true \&AuthType=ip,uid\&db=rih\&AN=A78817\&site=eh ost-live.

Woolf, Virginia. A Room of One’s Own. Feedbooks, 1929. http://seas3.elte.hu/coursematerial/PikliNatalia/Virginia_Woolf_-_A_Room_of_Ones_Own.pdf

Moments of Being. Edited by Jeanne Schulkind, Harcourt Brace Jovanovich Publishers, 1985.

Youens, Susan. "Suleika." Hyperion Records, https://www.hyperionrecords.co.uk/dw.asp?dc=W13033_GBAJY1075329. Accessed on November 28, 2017. 